\title{
Analisis Wacana Kritis Komentar Seksual dalam Media Sosial Twitter Laki-Laki Berekspresi Gender Feminin
}

\author{
Nara Garini Ayuningrum \\ Jurusan Ilmu Komunikasi, Universitas 17 Agustus 1945, Surabaya \\ "Penulis Koresponden: naragarini@gmail.com
}

\section{ABSTRAK}

Pandemi COVID-19 memaksa masyarakat untuk mengisolasi diri mereka masing-masing demi mencegah penyebaran virus. Hal ini meningkatkan aktivitas daring para individu demi memenuhi segala kebutuhan dan kewajiban. Tidak hanya aplikasi berbasis jasa yang mengalami peningkatan aktivitas pengguna, tetapi juga aplikasi media sosial, salah satunya adalah Twitter. Dengan berbagai fitur yang ditawarkan, Twitter tidak hanya mempermudah individu untuk berkomunikasi dengan orang-orang yang dikenalnya, tetapi juga membuka peluang untuk berinteraksi dengan pengguna lain tanpa adanya batasan. Twitter memungkinkan penggunanya untuk mengunggah swafoto dan membiarkan pengguna lain untuk mengomentari swafoto/unggahan tersebut. Dalam penelitian ini, penulis akan menganalisis komentar-komentar bernada seksual yang ada pada swafoto akun@dododid_selama periode tahun 2020. Dengan menggunakan metode analisis wacana kritis Norman Fairclough, peneliti menemukan 3 wacana besar terkait swafoto laki-laki berekspresi gender feminin, yaitu wacana cantik = perempuan, wacana objektifikasi dan stigma dan stereotipe. Melalui penelitian ini penulis juga menemukan bahwa kekerasan gender berbasis online bisa dialami oleh siapa saja dalam bentuk yang bermacam-macam.

Kata Kunci: COVID-19; KGBO; Media Sosial; Twitter; Gender; Analisis Wacana Kritis; Norman Fairclough

\section{ABSTRACT}

The COVID-19 forces people to isolate themselves to prevent the spread of the virus. COVID-19 increases the online activities of individuals to meet all their needs and obligations. Not only service-based applications that increased user activity, but also social media applications, which is Twitter. With the various features that Twitter offers, it not only makes it easier for individuals to communicate with people they know, but also opens up opportunities to interact with other users without any restrictions. Twitter allows its users to upload selfies and allows other users to comment on those selfies/uploads. In this research, authors analyzed sexually comments on@dododid_selfies during the 2020 period. Using Norman Fairclough's critical discourse analysis method, authors found 3 major discourses related to selfies of men with feminine gender expression, that are beautiful discourse $=$ women, objectification discourse and stigma and stereotypes. Through this study the author also found that online-based gender violence can be experienced by anyone in various forms.

Kata Kunci: COVID-19; Online-based Gender Violence; Social Media; Twitter; Gender; Critical Discourse Analysis; Norman Fairclough

\section{PENDAHULUAN}

Virus COVID-19 memaksa hampir seluruh manusia di berbagai belahan bumi untuk mengisolasi diri, sehingga mempengaruhi bagaimana manusia menjalani kehidupannya sehari-hari. Hampir seluruh sekolah dan universitas dilarang melakukan kegiatan. Begitupun beberapa kantor dan ruang-ruang publik seperti restoran, minimarket, pasar dan pusat perbelanjaan. Penggunaan aplikasi-aplikasi berbasis jasa meningkat pesat karena semua urusan harus diselesaikan dari rumah, begitupula dengan penggunaan media sosial. Masyarakat yang sebelumnya bersosialisasi secara langsung, kini harus memanfaatkan berbagai aplikasi pesan dan media sosial untuk berkomunikasi. 
Dalam penelitian kali ini, penulis mengkhususkan pada penggunaan media sosial Twitter. Fiturfitur yang ditawarkan oleh Twitter, memungkinkan tiap pengguna untuk menulis dan mengunggah, membaca, mengomentari, mengunggah kembali (retweet), menyukai (like) dan membagikan sebuah unggahan (share), atau dalam media sosial ini disebut tweet. Ada pula fitur lain yang bersifat pribadi seperti berbagai pesan secara langsung (direct message), yang hanya dapat diakses dan dilihat oleh para pengguna yang terlibat dalam percakapan. Selain berbagi pesan langsung (direct message), setiap aktivitas yang dilakukan oleh pengguna dapat dilihat pula oleh pengguna lain, selama akun Twitter yang dimilikinya tidak menggunakan mode pribadi (private account). Para pengguna dapat saling mengomentari (reply) setiap tweet yang diunggah oleh pengguna lain. Fitur ini tidak hanya diperuntukkan bagi pengguna yang saling mengenal atau mengikuti akun Twitter satu sama lain, tapi diperuntukkan bagi semua pengguna tanpa terkecuali. Hal ini memungkinkan terjadinya percakapan atau komunikasi terbuka antara pemilik tweet dengan pengguna yang mengomentari tweetnya. Tidak hanya satu dua pengguna yang mengomentari, tapi bisa ratusan, bahkan ribuan pengguna lain turut mengomentari tweet yang diunggah. Jenis tweet pun bermacam-macam, ada pengguna yang membagikan pengalaman mereka, informasi mengenai kesehatan atau produk-produk yang bermanfaat, trivia, hingga kegiatan sehari-hari. Fitur lain yang ditawarkan oleh Twitter adalah mengunggah foto, video, rekaman suara hingga siaran langsung. Fitur ini seringkali dimanfaatkan oleh para pengguna untuk membagikan foto atau kegiatan seharihari mereka, atau sebuah peristiwa penting, seperti demo dan bencana alam.

Dengan fitur-fitur yang ditawarkan oleh Twitter, khususnya dengan fitur like dan retweet, sebuah tweet dapat dengan mudah dilihat dan ditemukan oleh pengguna lain. Itulah mengapa adanya fenomena "viral", karena mudahnya seseorang melihat dan membagikan sebuah unggahan. Dalam media sosial Twitter, terdapat jenis-jenis tweet yang digandrungi, yang akan mendapatkan banyak reply, like, retweet dan share, seperti tweet yang berisi tentang informasi kesehatan, politik, resep masakan, rekomendasi produk, opini terhadap peristiwa-peristiwa aktual hingga meme. Belakangan tweet-tweet bertema motivasi, kutipan (quote) dan swafoto juga menjadi tweet yang banyak digandrungi. Tidak jarang sebuah tweet swafoto bisa mendapatkan ratusan hingga ribuan reply, retweet dan like. Berbeda dengan media sosial Instagram, fitur utama yang ditawarkan oleh Twitter bukanlah membagikan foto dan video, tetapi pesan teks sepanjang 280 karakter, sehingga tweet-tweet swafoto memenuhi linimasa baru saja terjadi belakangan ini. Dilansir dari website resmi detik.com ${ }^{11}$ peningkatan aktifitas pengguna Twitter di Indonesia, baik pengguna lama maupun baru, kembali meningkat pada tahun 2019. Media sosial Twitter mengalami penurunan aktifitas pengguna pada tahun $2015^{2}$. Penurunan aktivitas penggunaan Twitter pada dapat dipengaruhi oleh adanya aplikasi media sosial lain seperti Facebook dan Instagram yang

\footnotetext{
${ }^{1}$ Virginia Maulita Putri, “Tahun 2019, Twitter Kembali Jaya di Indonesia”, diakses pada 26 Maret 2021, https://inet.detik.com/mobile-apps/d-4905885/tahun-2019-twitter-kembali-jaya-di-indonesia

${ }^{2}$ Hani Nur Fajria, "Pengguna Aktif Twitter Terus Menurun”, diakses pada 26 Maret 2021, https://www.cnnindonesia.com/teknologi/20160211135935-185-110345/pengguna-aktif-twitter-terus- menurun
} 
menawarkan fitur-fitur yang dinilai lebih menarik saat itu, seperti unggah foto dan video. Sehingga mungkin tren mengunggah swafoto pada Twitter sedikit banyak dipengaruhi oleh penggunapengguna aplikasi Instagram dan Facebook, yang mulai aktif kembali atau baru saja membuat akun baru.

Dengan kebebasan yang ditawarkan oleh Twitter, para pengguna dengan bebas mengunggah konten apapun selama tidak melanggar ketentuan yang ditetapkan oleh Twitter seperti mengunggah konten pornografi atau perilaku kebencian. Hal ini menyebabkan terjadinya pertukaran wacana yang masif di antara para pengguna Twitter. Seorang pengguna dengan bebas mengutarakan opini dan pemikirannya terhadap sebuah peristiwa, maupun mengomentari opini dan pemikiran pengguna lain. Begitupula pada swafoto. Ketika seorang pengguna mengunggah tweet swafotonya, pengguna lain dengan mudah mengomentari tweet tersebut. Tanpa adanya larangan tertulis, tidak jarang para pengguna menggunakan kata-kata yang melecehkan ketika menanggapi tweet orang lain.

Data yang dihimpun oleh komnas perempuan pada tahun 2020 menyatakan ada 940 kasus kekerasan siber atau kekerasan gender berbasis online yang terjadi pada perempuan dan kelompok minoritas. Kekerasan ini dapat berupa penguntitan siber; intimidasi; pelecehan siber; pelecehan di berbagai platform; serangan melalui komentar; mengakses, mengunggah, atau menyebarkan foto, video atau klip audio intim tanpa persetujuan; mengakses atau menyebarkan data pribadi tanpa persetujuan; doxing dan pemerasan seksual ${ }^{33}$. Lonjakan jumlah kasus kekerasan gender berbasis online diduga karena adanya pembatasan mobilitas yang terjadi akibat pandemi COVID-19, sehingga terjadi peningkatan aktivitas daring pada masyarakat.

Seperti yang dikatakan oleh Sri Wiyanti Eddyono pada webinar Love Scam yang diadakan oleh Pusat Studi Wanita UGM pada tanggal 6 Maret 2021 lalu, bahwa jarak menjadi aset atau modal bagi pelaku kekerasan siber untuk melakukan kejahatannya. Selain itu, mudahnya akses untuk membuat akun pada media sosial Twitter, dengan menggunakan nama dan profil foto apapun (anonim), seseorang dapat dengan bebas menggunakan akun Twitternya. Dengan segala "ketidakpastian" yang ada, sedikit sekali korban kekerasan gender berbasis online melaporkan pelakunya, apalagi pada kasus-kasus yang dinilai tidak memiliki kerugian materil, seperti pelecehan seksual. Belum lagi stigma yang dilekatkan pada korban pelecehan seksual di Indonesia, semakin mengurungkan niat para korban untuk melapor.

Penulis melihat adanya sebuah peristiwa baru yang terjadi di tengah meningkatnya penggunaan media sosial Twitter selama COVID-19. Dengan masifnya pertukaran wacana yang terjadi, Twitter menjadi salah satu tempat aman (safe place) bagi banyak orang untuk mengekspresikan diri mereka sendiri. Wacana terhadap kelompok-kelompok minoritas seperti LGBT atau penganut

\footnotetext{
${ }^{3}$ Komisi Nasional Anti Kekerasan Terhadap Perempuan, Perempuan Dalam Himpitan Pandemi: Lonjakan Kekerasan Seksual, Kekerasan Siber, Perkawinan Anak dan Keterbatasan Penanganan di Tengah COVID-19. Catahu 2021: Catatan Tahunan Kekerasan Terhadap Perempuan Tahun 2020 (Jakarta: Komnas Perempuan, 2021), 95.
} 
keyakinan tertentu, mendapat "sambutan" baik dari mayoritas pengguna Twitter di Indonesia, sehingga banyak sekali individu yang memberanikan diri untuk mengekspresikan identitasnya melalui unggahan tweet, foto atau video pada laman akun Twitter mereka. Pada artikel ini, penulis meneliti komentar yang ditinggalkan oleh pengguna lain pada unggahan swafoto dalam akun Twitter@dododid_selama tahun 2020. Penulis menyadari bahwa kekerasan gender berbasis online, khususnya pelecehan seksual tidak hanya didapatkan oleh perempuan, tetapi juga laki-laki. Dalam swafoto yang diunggah @dododid_penulis menemukan banyak sekali komentar bernada seksual yang ditinggalkan oleh para pengguna lain. Pemilik akun@dododid_adalah seorang lakilaki berekspresi gender feminin, dengan jumlah pengikut 42.900. Dodi aktif menggunakan Twitter sejak tahun 2019 hingga saat ini. Menggunakan analisis wacana kritis Norman Fairclough, penulis mencoba untuk mengetahui wacana apa yang meliputi laki-laki berekspresi gender feminin, melalui komentar berbau seksual yang diterimanya, dalam media sosial Twitter.

\section{TINJAUAN PUSTAKA}

Menggunakan kata kunci "kekerasan gender berbasis online" dan "gender-based violence online" melalui kolom pencarian google menghantarkan penulis pada ratusan artikel dan penelitian. Penulis menemukan 2 artikel yang secara garis besar memiliki tema yang sama, yang pertama adalah sebuah artikel yang berjudul Changing Forms and Platforms of Misogyny: Sexual Harassment of Women Journalists on Twitter oleh Richard Rego (2018). Serupa dengan penelitian yang penulis lakukan, Rego meneliti sekumpulan komentar (reply) yang ada pada tweet yang diunggah oleh Barkha Dutt, Sagarika Ghose dan Rana Ayyub, yang ketiganya berprofesi sebagai jurnalis. Dengan menggunakan metode penelitian analisis wacana kritis feminisme, Rego menemukan sekumpulan wacana yang sama dalam komentar-komentar yang diunggah oleh pengguna Twitter pada tweet ketiganya. Rego menyimpulkan bahwa komentar-komentar yang ditujukan kepada Barkha Dutt, Sagarika Ghose dan Rana Ayyub adalah sebuah gender trolling, yaitu varian lain dari misoginis, "trolls are characterised by sadistic tendencies, deriving pleasure by shaming and humiliating their targets, and indulging in disruptive, narcissistic behaviour, triggering conflicts among the community of users" (Rego, 472:2018). Melalui artikel ini, penulis melihat bagaimana metode penelitian yang dilakukan dalam media sosial Twitter, khususnya menganalisis kolom komentar. Namun penulis dan penelitian ini menggunakan 2 metode yang berbeda.

Penelitian yang kedua berjudul, Covid-19, Harassment and Social Media: A Study of GenderBased Violence Facilitated by Technology During the Pandemic oleh Mochamad Iqbal Jatmiko, Muh. Syukron dan Yesi Mekarsari (2020). Penelitian ini mengungkapkan bagaimana praktik kekerasan gender berbasis online terjadi di Indonesia selama pandemi COVID-19. Jatmiko, Syukron dan Mekarsari melakukan penelitian dengan menggunakan metode kualitatif, dimana ketiganya melakukan wawancara kepada 3 narasumber mengenai pengalaman kekerasan gender berbasis online yang mereka alami. Dalam penelitian ini ditemukan bahwa ketiganya mengalami pola kekerasan yang sama, yaitu penyebaran foto dan video intim pribadi mereka oleh pihak kedua, yang dalam kasus ini adalah agensi tempat subjek bekerja dan mantan pacar. Foto dan video intim 
ketiganya tidak hanya disebarluaskan di media sosial Twitter, tetapi juga diperjualbelikan. Pada akhir penelitian Jatmiko, Syukron dan Mekarsari (2020) menyimpulkan bagaimana penggunaan teknologi yang meningkat selama pandemi COVID-19 mempermudah pelaku untuk melakukan kekerasan. Melalui artikel ini penulis mengetahui bagaimana kekerasan gender berbasis online yang terjadi di Indonesia, khususnya selama pandemi COVID-19.

\section{METODOLOG}

Penelitian ini menggunakan metode analisis wacana kritis Norman Fairclough. Analisis wacana kritis (AWK) adalah analisis yang berfokus terhadap wacana bukan semata sebagai studi bahasa berkenaan dengan aspek kebahasaannya saja melainkan juga dengan konteksnya (Eriyanto, 2000:07). "Critical discourse analysis (CDA) is a type of discourse analytical research that primarily studies the way social power abuse, dominance, and inequality are enacted, reproduced, and resisted by text and talk in the social and political context" (Van Dijk, 2001:352). Analisis wacana kritis adalah suatu jenis penelitian analisis wacana yang menitikberatkan kepada kajian bagaimana penyalahgunaan kekuasaan, dominasi, dan ketidaksetaraan dibuat, diproduksi, dan ditolak melalui teks atau lisan di dalam konteks sosial dan politik. (Fauzan, 2014). Analisis wacana kritis dalam konteks sehari-hari digunakan untuk membangun kekuasaan, ilmu pengetahuan baru, regulasi dan normalisasi, dan hegemoni. Analisis wacana kritis juga digunakan untuk mendeskripsikan sesuatu, menerjemahkan, menganalisis, dan mengkritik kehidupan sosial yang tercermin dalam teks atau ucapan (Fauzan, 2014:02). Van Dijk, Wodak, Fairclough dan Van Leuween seringkali mengatakan bahwa tujuan utama analisis wacana kritis adalah untuk mengungkap adanya ketidakdilan dalam wacana pada antar peserta wacana. Dengan demikian, dalam analisis wacana kritis, teks tidak dilihat semata sebagai teks dengan berbagai perangkat tekstual dan strukturalnya, melainkan juga sebagai praktek kewacanaan dan konteks sosial yang melatarinya. (Bawarti, 2014).

Wacana sebagai praksis sosial mengarahkan fokusnya untuk menganalisis institusi, organisasi, relasi kelompok, struktur, proses sosial-politik untuk dipelajari pada tingkat wacana, komunikasi dan interaksi (Haryatmoko, 2017:23). Analisis wacana kritis memadukan dan menjelaskan hubungan antara keduanya, termasuk sturktur wacana dan struktur masyarakat. Dengan memperhitungkan proses semiosis itu, analisis wacana kritis menurut fairclough, perlu memperhatikan 3 dimensi (Haryatmoko, 2017:23); (1) teks, (2) praktik diskursif, dan (3) praktik sosial. Fairclough (2001) membagi 3 jenis analisis berbeda, terkait dengan dimensi teks, praktik diskursif dan praktik sosiokultural, yaitu:

1. Dalam wilayah teks, deskripsi digunakan untuk melakukan analisis teks untuk mendapatkan gambaran bagaimana teks dipresentasikan. Pada tahap deskripsi ini, Fairclough juga menekankan pentingnya investigasi terhadap proses produksi teks yang mencakup konteks sosialkultural yang melatarbelakangi lahirnya teks tersebut.

2. Interpretasi digunakan untuk menganalisis proses, yakni menginterpretasikan teks itu sendiri dan bagaimana teks dikonsumsi dan diinterpretasikan oleh pembaca. Dengan 
menggunakan representasi pola-pola tertentu dari tipe-tipe diskursus yang berbeda, penafsir dapat menentukan tipe diskursus yang sedang dianalisis dan tatanan wacananya. Adapun point dari teks merupakan ringkasan atau topik dari teks tersebut (Fairclough, 2001:131).

3. Eksplanasi diorientasikan untuk menggambarkan diskursus sebagai bagian dari praktik sosial dan menunjukkan determinasinya terhadap struktur sosial dan efek reproduktifnya terhadap struktur-struktur tersebut, baik efeknya memapankan ataupun mengubah struktur. Struktur sosial yang menjadi fokus analisis adalah relasi kekuasaan. Fairclough menekankan dua hal yang harus dianalisis yakni, determinan yaitu relasi kekuasaan yang menentukan diskursus dalam proses perjuangan sosial dan efek yang dihasilkan diskursus tersebut.

\section{HASIL \& PEMBAHASAN}

Selama tahun 2020, kurang lebih terdapat 92 swafoto yang diunggah pada akun Twitter (adododid_. Pada tiap swafoto, terdapat 100-1800 komentar yang ditinggalkan oleh pengguna lain. Penulis mengkategorikan komentar-komentar yang ditinggalkan, sesuai dengan wacana yang meliputi.

\section{Cantik $=$ Perempuan}

Kalimat "Dodi tete kamu mana? Kok gak gede" dan "cantik-cantik gaada ttnya", adalah beberapa komentar yang penulis temukan dalam kolom komentar unggahan swafoto@dododid_.Dalam analisis teks, penggunaan istilah tete atau payudara mengacu pada ciri- ciri biologis yang dimiliki oleh laki-laki dan perempuan. Namun pada kalimat berikutnya yaitu "kok gak gede" dan "gaada ttnya" mengacu pada payudara perempuan, dimana payudara perempuan di Indonesia memiliki ukuran yang lebih besar. Payudara sendiri menjadi lambang atau tanda bagi seseorang yang berjenis kelamin perempuan, yang berfungsi untuk menyusui. Dimana di Indonesia, hanya perempuan yang bisa mengandung dan menyusui bayi. Payudara yang besar kemudian menjadi pembeda "yang alami" antara fisik laki-laki dan perempuan. Sehingga dapat dikatakan bahwa komentar yang diunggah oleh@eflLnIkcuFecIN dan@syyu (gambar 1) dalam dimensi praktik diskursif, memiliki interprestasi bahwa wacana cantik hanya dimiliki oleh perempuan, yang ditandai dengan ciri-ciri biologis yaitu memiliki payudara yang besar. Kalimat-kalimat diatas juga menunjukkan bahwa orang-orang yang secara biologis tidak dilahirkan sebagai perempuan, tidak berhak atau tidak bisa dikatakan cantik. Walaupun secara fisik Dodi memenuhi kriteria wacana cantik di Indonesia, seperti rambut hitam panjang, tubuh tinggi langsing, kulit putih, hidung mancung dan bibir merah, namun warganet tetap mempertanyakan ciri- ciri biologis yang seharusnya dimiliki oleh-oleh orang yang dilabeli kata "cantik".

Dalam dimensi praktik sosial, laki-laki berekspresi gender feminin seperti Dodi di Indonesia, belum banyak tampil secara terbuka di tengah masyarakat. Mayoritas penduduk Indonesia beranggapan bahwa hanya laki-laki yang bisa berpenampilan maskulin dan hanya perempuan yang bisa berpenampilan feminin, bukan sebaliknya. Judith Butler (1990) dalam bukunya menjelaskan 
bagaimana gender bukanlah sebuah identitas yang stabil. Gender terbentuk atas adanya pengulangan tindakan yang dilakukan secara terus menerus. Hal ini menunjukkan bahwa gender tidaklah ditentukan oleh jenis kelamin seseorang saat ia dilahirkan, melainkan melalui sebuah tatanan sosial. Seorang individu akan terus merubah, memperbaiki, dan mengulangi sebuah tindakan secara terus menerus untuk membentuk gendernya, "...the gendered body as the legacy of sedimented acts rather than a predetermined...” (Butler, 523:1988). @eflLnIkcuFecIN dan @_ssyu tidak lain adalah representasi dari mayoritas masyarakat di Indonesia, yang terhegemoni dengan wacana feminin dan maskulin yang linier. Di Indonesia, terjadi perbedaan peran dan karakter yang signifikan antara laki-laki dan perempuan. Dodi yang dilahirkan dengan ciri-ciri biologis laki-laki, namun memiliki ekspresi gender feminin, akan mengacaukan pembagian peran dan karakter tersebut. Dengan adanya Dodi, gambaran atau representasi mengenai laki-laki akan bertambah (bila tidak bisa dikatakan bergeser), menjadi laki-laki yang tidak lagi harus memiliki rambut pendek cepak, tetapi juga bisa memiliki rambut panjang yang halus. Laki- laki tidak lagi harus memiliki tubuh yang gagah, tetapi juga bisa memiliki tubuh yang semampai. Adanya pergeseran ini mungkin akan merubah peran laki-laki dan perempuan di ruang-ruang publik dan institusi-institusi formal, mengenai cocok dan tidak cocoknya laki- laki dan perempuan pada profesi tertentu.

\section{Objektifikasi}

Dalam analisis teks, penggunaan kata "ngaceng" dan "sange" merujuk pada rangsangan seksual yang terjadi pada seorang individu, dalam kasus ini pada@hipsterpeep, @saputra_dodiidan @irvnsyahh, ketika melihat swafoto yang diunggah pada akun @dododid_(gambar 2). Kata "hampir" yang ditulis 2 kali pada 2 komentar yang berbeda mengisyaratkan adanya perubahan tindakan setelah sebuah peristiwa, dalam kasus ini setelah mengetahui bahwa Dodi adalah lakilaki, "lah lu cowo? Hmpir aja w engas". Dalam dimensi praktik diskursif yang dikemukakan Fairclough, komentar-komentar di atas mengisyaratkan adanya wacana objektifikasi terhadap individu-individu yang terlihat cantik, "hati-hati ada yg keliru terus buat bacol". Bila kalimatkalimat tersebut dibedah secara mendalam, objektifikasi ini ditujukan sebenarnya untuk perempuan, karena penggunaan kata "hampir" dan "hati-hati ada yg keliru". Para pengguna Twitter ini merasakan rangsangan seksual ketika melihat swafoto yang diunggah Dodi, namun mengurungkan niatnya setelah mengetahui bahwa Dodi adalah laki-laki.

Dalam dimensi praktik sosial, di Indonesia terdapat relasi kuasa yang timpang antar laki-laki dan perempuan. Dengan sistem patriarki yang kuat, objektifikasi terhadap perempuan karena berada di ruang publik, adalah sebuah hal yang wajar. Sehingga ketika Dodi berpenampilan feminin, ia pun diobjektifikasi walaupun ia seorang laki-laki. Hal ini mungkin berhubungan dengan apa yang dikemukakan oleh Laura Mulvey (dalam Durham dan Kellner, 2006) soal Male Gaze. Foto atau dunia fotografi sangat erat kaitannya dengan dunia laki-laki (Handayani, 2017), atau sebuah kegiatan yang dimaskulinkan. Model sebagai objek fotografi sangat identik dengan pekerjaan perempuan, walaupun pada dasarnya model dapat berupa apapun. Model perempuan selalu dinilai lebih menarik dibandingkan dengan objek-objek lain. Pada fotografi, laki-laki berperan sebagai 
gaze atau tatapan sedangkan perempuan berperan sebagai gambar atau objek (Handayani, 2017), sehingga mengobjektifikasi perempuan melalui fotonya seakan adalah sebuah hal yang lumrah. Bahkan ketika swafoto diproduksi oleh dirinya sendiri, perempuan tetap tidak lepas dari pandangan objektifikasi bernada merendahkan. Tidak bisa dipungkiri bila swafoto yang diproduksi oleh masyarakat awam seperti Dodi, mereproduksi gambar-gambar (dalam segi pose, angle dan elemen tertentu) yang ia lihat dalam ruang publik, yang tentu saja didominasi oleh male gaze, seperti iklan produk, poster film dan baliho-baliho. Gambar- gambar yang berada di ruang publik, apalagi dijadikan sebagai iklan atau apapun oleh institusi formal, tentu memiliki citra sebagai gambar yang "baik".

\section{Stigma dan Stereotipe}

Pada unggahan swafoto lainnya, penulis menemukan komentar-komentar yang diunggah oleh pengguna lain (gambar 3). Penulis menemukan beberapa komentar serupa dengan gambar-gambar di lainnya (gambar 1 dan gambar 2). Dalam analisis teks, kata "banci" dan "mangkal" beberapa kali digunakan oleh pengguna lain ketika mengomentari swafoto pada akun@dododid_.Dalam KBBI, kata "banci" memiliki arti tidak berjenis laki-laki dan tidak berjenis perempuan, yang disamakan dengan kata "wadam" dan "waria". Namun dalam kehidupan sehari-hari, kata "banci" mengalami peyorasi atau pengurangan makna. Kata "banci" seringkali digunakan untuk mengolok-ngolok atau mengejek seseorang yang memiliki ekspresi gender (yang dinilai) berbeda dengan jenis kelaminnya. Dalam dimensi praktik diskursif, banci merujuk pada laki-laki yang berdandan feminin untuk mencari uang (motif ekonomi), seperti pengamen, penari/penyanyi jalanan dan PSK. Di Indonesia, individu yang memiliki ekspresi gender berbeda dengan jenis kelaminnya, tidak mempunyai banyak peluang untuk bekerja, sehingga menjadi pengamen, penari/penyanyi jalanan dan PSK adalah satu-satunya pekerjaan yang dapat mereka geluti. Sejalan dengan apa yang dikatakan Butler (1998:522) "Discrete genders are part of what 'humanizes' individuals within contemporary culture; indeed, those who fail to do their gender right are regularly punished", pembatasan ruang profesi bagi laki-laki berekspresi gender feminin adalah sebuah bentuk hukuman karena dianggap melanggar batas kewajaran dan norma yang berkembang di tengah masyarakat Indonesia.

Hal ini tentu mempengaruhi dimensi praktik sosial dimana stigma dan stereotipe melekat pada mereka yang memiliki ekspresi gender berbeda dengan jenis kelaminnya, khususnya laki-laki berekspresi gender feminin. Meskipun bidang pekerjaan yang mereka geluti sama sekali bertolak belakang dengan pengamen, penari/penyanyi jalanan dan PSK, namun julukan "banci" akan melekat. Belum lagi representasi "banci" di media massa yang identik digunakan sebagai bahan lelucon dan menakutkan, melanggengkan stigma negatif yang ada. Stigma negatif tersebut kemudian menyebabkan adanya perbedaan nilai yang diberikan oleh masyarakat kepada laki-laki berekspresi gender feminin dengan laki-laki berekspresi gender maskulin. Dengan sistem patriarki yang kuat di tengah masyarakat, tentu saja Dodi dianggap melakukan "perlawanan" karena berani mengekspresikan dirinya dengan feminin, sehingga mengolok-ngolok atau melakukan praktik penamaan terhadap Dodi adalah upaya untuk merepresi individu lain melakukan hal serupa. Hal 
ini berkaitan dengan nilai individu berdasarkan gender di tengah masyarakat. Di Indonesia, orangorang dengan ekspresi gender maskulin, baik laki-laki dan perempuan akan dinilai lebih "tinggi" daripada mereka yang berekspresi gender feminin. Sehingga Dodi dan individu lain yang serupa, akan mengalami pengucilan dan perundungan dari pihak-pihak yang merasa memiliki nilai lebih tinggi (laki-laki dan perempuan cisgender). Hal ini berhubungan dengan wacana objektifikasi sebelumnya, bahwa adanya relasi kuasa antara si maskulin dengan si feminin, menyebabkan salah satunya merasalebih "kuat" dan demi melanggengkan kekuasaan itu, ia akan menyerang individu lain yang berada "dibawahnya".

\section{KESIMPULAN DAN REKOMENDASI KEBIJAKAN}

Kasus kekerasan gender berbasis online yang meningkat sepanjang tahun 2020 dikarenakan penggunaan internet yang masif selama COVID-19, tidak hanya dirasakan oleh perempuan, tetapi juga laki-laki. Pelecehan seksual yang diterima oleh Dodi dalam media sosial Twitternya membuktikan bahwa KGBO bisa menimpa siapa saja tanpa terkecuali. Ketimpangan relasi kuasa atas gender di Indonesia seringkali membuat kita terlalu fokus pada salah satu gender, yaitu perempuan yang dinilai lebih rentan, sehingga menyampingkan kelompok-kelompok lain. Wacana-wacana yang ditemukan dalam kolom komentar unggahan swafoto Dodi menunjukkan bahwa laki-laki dengan ekspresi gender feminin masih menjadi liyan, di tengah masyarakat Indonesia. Media sosial Twitter seakan hanya menjadi replika kehidupan masyarakat Indonesia dalam bentuk daring. Stigma, strata sosial dan stereotipe tetap tidak bisa hilang dari kehidupan sehari-hari masyarakatnya.

Pengguna media sosial Twitter, adalah sasaran empuk bagi pelaku pelecehan seksual karena sifatnya yang bebas, anonim dan luas. Pelaku dapat dengan mudah menghilangkan jejaknya dengan menghapus akun Twitternya. Dengan adanya seperangkat aplikasi lain pun, seperti photoshop, bukti-bukti yang dikumpulkan korban, seperti tangkapan layar atau gambar, tidak bisa menjadi bukti yang kuat. Layanan hotline dan konsultasi bagi para pelecehan seksual dalam dunia siber sekiranya perlu dibarengi dengan kelengkapan teknologi dan sumber daya manusia yang mumpuni dalam bidang ini. Dunia siber hingga saat ini belum menjadi spesialis banyak orang, sehingga sulit untuk secara maksimal melacak pelaku pelecehan seksual berbasis daring. Selain itu, peneliti rasa diperlukan adanya upaya dari pemerintah dan lembaga-lembaga juga institusi formal seperti media, untuk menggunakan teks yang ramah dan bersifat netral untuk menyudahi stigma dan stereotip yang melekat pada korban pelecehan seksual. Semoga penelitian ini menjadi salah satu bukti bahwa pelecehan seksual sama sekali tidak didasarkan pada gender apalagi pakaian korban.

\section{DAFTAR PUSTAKA}

Buku:

Butler, Judith, 1990, Gender Trouble, New York: Routledge

Eriyanto. 2000. Analisis Wacana; Pengantar Analisis Teks Media. Yogyakarta: LKiS. 
Fairclough, Norman. 2001. Language and Power. England: Pearson Educated Limited Haryatmoko. 2017. Critical Discourse Analisis (Analisis Wacana Kritis). Landasan Teori,

Metodologi dan Penerapan. Jakarta: Rajawali Press

Durham, Meenakshi Gigi dan Douglas Kellner, 2006. Media and Cultural Studies. Oxford: Well Publishing Ltd

Artikel:

Butler, Judith, 1988, "Performative Acts and Gender Constitution: An Essay in Phenomenology and Feminist Theory", Theatre Journal, Vol. 40, No. 4, hal. 519-531

Fauzan, umar. 2014. Analisis Wacana Kritis dari Model Norman Fairclough hingga Mills.

Jurnal Pendidik, Vol.06, No.01

Handayani, Rivi, 2017, "Male Gaze Dalam Fotografi Model: Objektifikasi Dan Komersialisasi Tubuh Perempuan", Jurnalisa, Vol. 3, No. 1, hal. 91-105

Jatmiko, Mochamad Iqbal, Muh. Syukron dan Yesi Mekarsari, 2020, "Covid-19, Harassment and Social Media: A Study of Gender-Based Violence Facilitated by Technology During the Pandemic", The Journal of Society and Media, Vol. 4, No. 2, hal. 319-347

Rego, Richard, 2018, “Changing Forms and Platforms of Misogyny: Sexual Harassment of Women Journalists on Twitter", Media Watch, Vol. 9, No. 3, hal. 437-446

Van Dijk, Teun. 2001. "Principles of Critical Discourse Analysis". Dalam Wetherel, Margaret, Taylor, Stephanie, \& Yates, Simon. (eds.). Discourse Theory and Practice. London: Sage Publication, hlm. 300 